\title{
Psychological approach to foreign language teaching
}

\author{
Tatyana Koshel, Natalya Manuylova, Nadezhda Revyakina*, and Elena Sakharova \\ Don State Technical University, department "World Languages and Cultures", 344000 \\ Rostov-on-Don, Russia
}

\begin{abstract}
This article deals with psychological mechanisms in professionally-oriented approach to learning foreign languages in nonlinguistic faculties of universities. This approach is very actual as it develops students' ability to speak foreign languages in specific professional, business, academic fields and situations, taking into account the characteristics of professional thinking. Psychological approach to foreign language teaching must be closely connected with culture oriented method as the leading one and recognized as a priority in the focus of the education renewal. In the article it is proved that cultural background is of great importance. A dry language course can teach the learners to say what is correct and acceptable only. But the learners also need to know what is appropriate for the target society and what is not. This can only be achieved if they learn about psychology, culture and traditions while learning foreign language. Methods: Mind - maps, pie charts, dramatization, projects, roleplaying to decide on which aspects of the culture the learners mostly need to learn about. The most important aspects of the English culture are defined and put into order of importance. Conclusions and Recommendations: suggesting ways of integrating psychology culture into the foreign language syllabus.
\end{abstract}

\section{Introduction}

Educational process in the university - a complex multi-dimensional unity. Due to the originality of the goals, objectives, content, forms and methods of the learning process, as well as due to the age and psychological characteristics of students technical University has its own specifics. Socio-economic conditions require graduates of technical universities such qualities as entrepreneurship, sociability, willingness to adapt to new working conditions. A specialist in the workplace has to deal with an abundant flow of information that he needs to properly accept, process and transmit, which is impossible without the presence of personal communicative reserves.

High level of concentration, attention switching, visual memory, high speed and accuracy of thought operations are also nesessary. Students of technical universities researchers have noted the strengthening of the introvertness of the individual in the learning process, the

\footnotetext{
* Corresponding author: nadinrev@ya.ru
} 
dominance of cognition motivation, desire for independence, lack of desire to dominate, awareness, responsibility, low emotionality when dealing with fellow students, a critical attitude towards the environment.

For a student of technical university an important stage of professional development is the development of mental abilities: significantly develop theoretical thinking, the ability to abstract, to make generalizations. There are qualitative changes in cognitive capabilities, nonstandard approach to different problems. To achieve greater efficiency in teaching students a foreign language, it is necessary "to look in the cultural world for something that binds specifically-professional to cultural" [1]. Training and education of professional-competent specialists capable of independent decision-making leads to the improvement of the economic, political and legal environment in our country.

\section{Research methods}

The existence of different approaches to the professional activities and personality of the teacher and student (TK Yesarev, VV Kraevsky, N.V., Kuzmina, VA Slastenin, etc.) [2] testifies to the scale of work in this direction. Whatever these approaches and directions (from classical - the transfer of knowledge and skills, to innovative - creating a comfortable, creatively organized environment for training and education), it is important to give a holistic description of the personality of a high school teacher who initiates activity and a creative search for students. Knowledge and the development of the personality of teachers and students remains the main concept of higher education today [3]. Higher school today needs a teacher who owns knowledge of his specialty, who loves his profession, students, decides to solve his professional tasks quickly and with maximum results.

Modern teacher should develop such professionally significant personal qualities as: conviction, professional ethics, goodwill, honesty, active life position [4]. Important factor in the upbringing and education of the personality of a student, is the attitude to the profession as the main task of life, the ability to self-giving, enthusiasm. We should not forget about the diversity of interests and spiritual needs, objectivity of self-esteem, optimism, patience, professional self-improvement and culture of behavior. The success of professional activity depends on the severity of these components, on the level of formation of the teacher's professional qualities. The teacher acts as a kind of filter of the whole educational process [5]. His most important task is to develop students' need for self-analysis, self-esteem, and self-development. It is necessary to awake the inner activity of the pupils, to maximally develop their independence in all spheres of life. Successful solution of these problems requires empathy from the teacher, i.e. the ability to see through the eyes of another person, the ability to put oneself in his place and empathize [6].

\section{Results}

Training of would be specialists should be completed by the formation of a personality and the acquisition of life and professional experience in a sociocultural context. The main idea of such an educational system is to replace the abstract learning process with the practical experience of students in real life. The emphasis is on the interests of the individual, the method of project training, psychological and pedagogical approaches. With such training, the teacher becomes the coordinator of the practical activities of students. Teachers today need to build their relations with students according to the laws of cultural life, in the professional sphere. "A student together with a teacher works for culture and with culture" [7]. For such training, of course, we need a new type of teacher, for whom such a method of pedagogical interaction would be organic and comfortable. The main thing is that the student 
has passed the key stages of the formation of his socio-cultural and professional consciousness. The teacher must be competent and from psychological point of view in order to properly organize the learning process, as well as to have certain personal and professional qualities.

\section{Discussion Questions}

Teachers of the chair "World Languages and Cultures" of the DSTU choose such forms of work that allow students to be interested, to increase their motivation in learning a foreign language. They choose creatively such forms and methods of work, that give students good opportunitis for their future life taking into account all the advanced experience of pedagogical thought in Russia and foreign countries. They draw the students' attention to the linguistic features of their native country in comparison with the elements of the language being studied. This work takes place, as a rule, in the context of a cultural approach. Not only linguistic, but also sociopolitical features of the native country and countries of the target language are subjected to a comparative analysis. If we are talking about traditions and customs, the comparison is particularly bright and interesting, because we are talking about holidays, festivals, ceremonies. In the professional field this is especially necessary, since the solution of important problems depends on national and cultural factors. Often the work on the study of the mentality of the British, their characteristics and habits is accompanied by computer presentations, videos that play an important role in the formation of sociocultural competence. This process is even more interesting when the students themselves are participants in role-playing games, dramatization, demonstrating certain features of the manifestation of the national character in the professional sphere. Modeling real-life situations of professional orientation is an integral feature of the occupation [8]. Future lawyers, economists, managers of the service sector should be aware of how negotiations of representatives of different cultures proceed, how business relations are established, what you need to know and be able to achieve the necessary results in business and legal aspects.

Interestingly held at the department "World Languages and Cultures" of DSTU such events as celebrations of Christmas, New Year, etc. This work is carried out both in class and during extracurricular activities. Students become active participants in scientific conferences, youth forums, and various meetings where it is necessary to express themselves as a fully developed personality, involved in the context of a professional approach. Such meetings become important milestones in the development of both a professional and a person of culture. This is facilitated by the knowledge gained in professional foreign language classes, which are held in the focus of the rapprochement of peoples and cultures. Teachers at the same time draw the attention of students to the national and cultural differences of countries, emphasizing common points and focusing on features [9].

Intercultural communication becomes decisive in almost all aspects of the activities in teaching students a foreign language. There are many examples of how this process takes place in the classroom. First of all, foreign language teachers are trying to explain to students what they are, the British. It is important to understand the national character of the British, who consider themselves law-abiding, polite and fair. For the true British England is not just a country, but a state of mind that determines their attitude to life. They rarely show their emotions. They are considered pedants, deprived of the spirit of cooperation. [10] For them, there is nothing more expensive than customs and traditions. All this and much more is explained by foreign language teachers after watching videos during classes. This helps students to better understand the nature and specifics of the English.

Intercultural communication in the implementation of extracurricular individual and independent work of students should also be mentioned [11]. So, many of students find examples, texts, articles in magazines, newspapers, the Internet, illustrating life and life, 
political and other aspects of life and activities of representatives of foreign countries, make reports comparing similar phenomena with Russian samples. Often, these messages are growing into discussions, presentations, games. Foreign language teachers are trying to teach students to remain patriots of their country in the assessment of foreign culture. Thus, in the classroom the values of Russian and British culture, the government, the legal system, economics, politics, and the culture of Russians and Englishmen are discussed in comparative terms. All this helps the upbringing and education of a person's culture in the professional field. After all, success is achieved not only by a competent specialist, but also by a man of exemplary culture who is able to apply his knowledge to achieve the desired goal [12].

The teacher acts in this process not only as a specialist in teaching a foreign language, but also as an intermediary between the native and foreign language culture, as an expert in the possibilities and technologies of intercultural learning [13]. This is especially important because it is about self-determination of the individual in culture and the development on this basis of an active life position, including in the professional sphere. "Culture is the basic component of the content of modern education. Culture is understood as spiritual values that have been mastered in activity, the development of a personality, its professional growth" [14].

\section{Conclusion}

It goes without sqaying that cognitive activity includes a wide range of tasks. It can be an integral part of various types of both educational and extracurricular activities of students, contributing to the deepening and expansion of the sphere of knowledge of students in their chosen specialty. We proceed mainly from the need to form a student's creative qualities of personality, needs and opportunities to go beyond the study material, the ability to selfdevelopment and continuous self-education.

In General, cognitive activity, acting as the most important factor in the development of students, is characterized by the need to expand the General Outlook, increase the intellectual level.

Thus, only taking into account the age characteristics of students, we can effectively develop their cognitive activity. The latter is one of the leading mechanisms that further ensure a high level of independence and responsibility of the student.

Psychological approach to education in the context of culture, the upbringing of human culture will help to overcome the crisis and allow Russia to take its right place among developed countries. "The goal of the national high school is to revive the national culture. At the same time, the issue of intercultural interaction between countries and peoples remains the key" [15]. This fully applies to the teaching of a foreign language in the professional fleld.

\section{References}

1. V.S. Bibler, School of dialogue of cultures. Ideas. Experiences. Problems (ALEPH, Kemerovo, 2017)

2. O.S. Gazman, Basic culture of personality: theoretical and methodological problems (Academy of Pedagogical Sciences of the USSR, Moscow, 1989)

3. A.L. Berdichevsky, N.N. Solovyova, Foreign languages in school. 6, 17-20 (1993)

4. E.I. Passov, Communicative foreign language education. The concept of development of individuality in the dialogue of cultures (Lipetsk, 2015)

5. I.A. Winter, Psychology of teaching foreign languages at school (Enlightenment, Moscow, 2016) 
6. A.A. Leontiev, Speech activity. Fundamentals of the theory of speech activity (Nauka, Moscow, 2017)

7. A.A. Leontiev, Language, speech, speech activity (Pedagogy, Moscow, 2015)

8. A.N. Leontiev, Selected psychological works in 2- $h$ volumes. (Pedagogy, Moscow, 2015)

9. B.F. Lomov, Questions philosophy. 8. 34-47 (2016)

10. Common European competences of foreign language proficiency: learning, training, assessment (Council of Europe, 2017)

11. G.V. Rogova, F.M. Rabinovich, T.E. Sakharova, Methods of teaching foreign languages in high school (Enlightenment, Moscow, 2017)

12. J.M. Dobson, Effective Techniques for English Conversation Groups (US Information Agency, Washington, D.C., 2018)

13. R.K. Johnson, The Second Language Curriculum (Cambrige University Press, Cambrige, 2016)

14. W.T. Littlewood, Foreign and Second Language Learning. Language Acquisition Research and its Implications for the Classroom (Cambrige University Press, Cambrige, 2017)

15. I.S.P. Nation, English Teaching Forum. 2, 20-24 (1989) 